\title{
Tuan Guru; A Leader of Rural Education Development
}

\author{
Aswasulasikin $^{1 *}$, Sri Pujiani ${ }^{1}$, Doni Septu Marsa Ibrahim ${ }^{2}$ \\ ${ }^{1}$ Dep. of Elementary School Teacher Education, Faculty Education, Universitas Hamzanwadi, Lombok-Indonesia \\ ${ }^{2}$ Mts. Mu'allimat NW Pancor, Lombok-Indonesia \\ *Corresponding author. Email: kien.ip12@gmail.com
}

\begin{abstract}
Tuan Guru as religious leaders and community leaders on the Lombok Island had a great influence in the middle of the community, because community leaders had advantages, both in science, positions, and directly from the offspring. Tuan Guru was as the central orientation of moral values and took responsibility in the process of religious life education, state and nation. Institutionally of Tuan Guru developed two types of education are formal and non-formal educations that fully support the purpose and nature of human education itself, which was the human form of true believers, had the quality of their moral and intellectual. Educational development through formal education developed by Mr. Master through the establishment of boarding school founded in which primary and secondary education consisting of: Islamic of Primary school, Islamic of junior high school, Islamic of Senior High School, While the development of non-formal education in rural areas was developed in the form of Diniyah.
\end{abstract}

\section{Keywords: Rural education, tuan guru}

\section{INTRODUCTION}

Autonomy in education gives flexibility schools and communities education developement according to social capital and culture capital of each region to enhance and improve the quality of education. Educational autonomy demands management of education in order accommodate the needs and to empower communities to effectively support education development. Decentralization of education in the implementation need of community participation to improve the output quality of education, especially the development process of education in rural.

Society has a role very important in the development process of education, either individually or as a group, because community participation is needed in education. Dwiningrum (2011) explains that in the implementation of education, there are three main reasons for public participation is very important; First, community participation is a means to obtain the conditions, needs and attitudes of local communities, without the participation of educational programs will fail. The second reason that the public will trust the education program if the people involved in the process preparation planig, execution, until education evaluation program, because they will know basically how educational programs are implemented. The third reason for participation to be important in the development of education as one might think that participation is a democratic right if the people involved in education. People have the right to determine the ideas and suggestions in the implementation of education development. The reality conditions rural communities in the regional autonomy and globalization is the responsibility of all parties, both government and society. Community involvement is inseparable from the role figures and influential role in it. For rural communities, religious leaders (Muslims) are very influential and have a central role in developing community activities, because most people are Muslim in Lombok. In the daily life of the people of Lombok calling Islamic leaders with the term "Tuan Guru" who has a social classification is different from ordinary people. Tuan Guru is not overly concerned with matters worldly, and not affected by changes in wave of technological developments. So that rural communities obedient, and very respectful of Tuan Guru. The Tuan Guru is a title given by the people of the Lombok island to a highly respected religious figure. Tuan Guru is not just a religious figure, but also as the founder, chairman, caretakers and owners of the boarding school, so the development of the boarding school on Lombok island to be very fast.

In addition, Tuan Guru has potential and innovation is significant in mobilizing the community, because of his leadership style as a spiritual leader make as community role models, and even beat position of formal leaders or local government. The term Tuan Guru as well Kyai in other areas such as Java, Bugis use unregretted term, while the term clerics already in general use throughout Indonesia (Yafie, 1997). Tuan Guru interpreted differently by other public figures, such as traditional leaders, political or government, as well as other figures because Tuan Guru has its own 
characteristics and different responsibilities. Tuan Guru has the functions and responsibilities of the community complex, linked to that, Tuan Guru known as leaders or religious leaders, because every behavior is based on religious teachings, namely the Qur'an and Sunnah, then help people to overcome any life issues (Badrun \& Ngongu, 1994, p.179). Thus, the existence and role in society Tuan Guru adjusted for changes in the social, cultural, and recognized by the community.

Status Tuan Guru was obtained as expertise in the field of religion, moral integrity, the ability to teach and preach (Fahrurrozi, 2018; Horikoshi, 1987; Ismah, 2016). Furthermore, the role of Tuan Guru is largely determined by his skills in interacting with the community; either individually or in groups and institutions, Tuan Guru is believed to have blessed, so as to have supernatural powers, magical, or other. The basic concept of this blessed as a gift associated with material prosperity, a healthy body, adequacy, luck, and magical powers. Barakah evidenced by the "presence of an individual, a strong character, moral life" (Geertz, 1971). Because blessings can be transferred from one owner to another, the popularity and authority of someone Tuan Guru or Kyai partially taken from strengths as a source of blessings. Process of education developments, the existence of Tuan Guru in a village on the island Lombok can accelerate the development process of education developed by rural communities, and have implications for the development of selfreliance in social life, especially in education development.

Tuan Guru in a village on the island of Lombok has the ability and power to attract public sympathy, and concern is formed by the ideas developed by the participation of Mr. Guru. Idea of Tuan Guru in education development is influenced by several things including: (1) the development of education in rural areas need the support of religious leaders who have a strong influence on society, in which the support is not necessarily addressed in the form of partisanship, but participation in the development program of education himself; (2) the development of education is community participation in the implementation of education, and the government only supports, facilitates, and fostering the community activities. In addition to the development of education, Tuan Guru also plays a role in matters of social nature. Thus, the role of the teacher in society Tuan functionally has a multidimensional function. The role and function are very varied, among others, includes the function of education, propaganda, social, cultural, and economic.

\section{METHOD}

This research is a qualitative perspective phenomenological (Paley, 2018; Ward, Comer, \& Stone, 2018), the study aimed to examine the role Tuan Guru in rural development with regard to the views and experiences of Tuan Guru subject of research. (Cypress, 2018; Donalek, 2004; Giorgi, 1994, 2009); Qualitative phenomenology is used so that the data relating to the views and experiences on the subject of education development. Researchers reveal the essence of the meaning experience of Tuan Guru in the development of education in rural. Phenomenological approach is used to study the events culture that makes the outlook on life, thoughts, meanings, attitudes and behavior of research subjects (Kruth, 2015; Law et al., 1998; Maggs-Rapport, 2000).

Research procedure (1) Data collection; Data were collected through observation, interviews, and documentation study. (2) Reduction of data; The gathered data is then compiled, edited, sorted coded and mapped to be described and analyzed in accordance with the order of the focus of research. Data reduction is necessary because of the number of data of each informant that are considered irrelevant to the focus of the research that needs to be simplified and reduced. (3) Presentation of data; The data further reduced presented systematically so easily mastered so easily in drawing conclusions or verification. (4) Verification; At the final stage of this research, the data that has been analyzed and then summarized and verified.

\section{RESULTS AND DISCUSSION}

Educational facilities developed by Tuan Guru could be the construction of madrasah in boarding school and comes with faculty who are part time teachers are on the payroll with the ability madrasah. Educational Develop is very important means of support with the aim to launch a program development functions are developed, as for the means to support the development of educational programs, which include physical building. To support the educational development process developed by Tuan Guru supported by employees who plays petrified process of implementation of educational programs. The employee is a vital element in supporting the implementation of development programs, especially in practical education in madrasa education. Employee status can be categorized into two, namely the permanent power or permanent teachers and staff are not permanent or temporary teachers. Such determination is based on two considerations: first, devotion of time in boarding school. "Old" means not only of time, but based on loyalty, and perseverance as a manifestation of their sincerity in devoting themselves.

Dedication to the foundation and madrasah usually applies to those outside the family of Tuan Guru; The second, based on the Tuan Guru lineage based on the assumption that they have a sense of responsibility and respect for the existence of Tuan Guru and boarding school. In order not to cause, understanding and confusion of the existing teaching force, then the granting of the status of teachers, it is at the discretion 
of Tuan Guru, the appointment was based on a decree (SK) of the Chairman of the Foundation. Under the decree, a person entitled to be appointed or removed for energy or teacher. Appointment and revocation of power made on the proposal of the headmaster under the foundation adapted to the purposes and needs of each (Aswasulasikin, Septu Marsa Ibrahim, 2016; Fahrurrozi, 2018; Liow, 2009).

The main target of the development of educational programs that the students who followed the formal education and the general public. Pupils who become targets of the educational program developed by Tuan Guru priority is the education of orphans / poor and students in boarding school. In addition, the majority of students come from cornerstone-intelligences that exist in the village, their background is the average family of farmers, farm workers, fishermen, traders or come from the middle class people down, this is the top priority in development field of education. Tuan Guru as community leaders know about it by seeing not the quantity or quality, but Tuan Guru see it from the kind of education that is needed by the community; starting from education as simple as Diniyah, discussions about religion and books, and recitation. Besides, Tuan Guru develop more complex education with all its variations, for example Pour Master builds the advice of education as a formal study, besides that it is also used as a venue for the development of student talent in order to compete at a global level. Strong public demand importance education institutions regulated by developing educational programs, then the outline of education developed in the Village Jerowaru seen through two type of education is formal education and informal education. The education program developed by Tuan Guru touched almost all groups, ranging from the economy class of the poor to the rich class. The educational program developed in the form of formal and informal can be described as follows:

\section{Formal of Education}

Development of a formal education program organized by Tuan Guru through the establishment of boarding school which included a madrasah consists of Tertiary Elementary School, Junior School and High School as a suggestion of formal education established by Tuan Guru together with the community. Formal education in the form of this madrasah stand on the initiative of Tuan Guru by involving local communities. This shows that efforts to establish madrassas Tuan Guru is one of my efforts to continue to improve public participation in the development process of education. Historically boarding school developed by Tuan Guru was originally a form of development of informal education, and then adjust to the development of education, and do not close themselves to the changing times, then developed into a formal education starting from the Elementary School, Junior School and High
School A. Towards the development of education more developed institutionally dominant, is basic education and secondary education programs.

In the development of formal education programs (Franquesa-Soler, Barraza, \& Serio-Silva, 2019; Morhardt, O'Hara, Zachrich, Wieneke, \& Rogalski, 2019) basic education and secondary education curricula tailored to the standards that have been established Ministry and the National Ministry of Education at the primary level and secondary education - In addition to developing a common program, the program of religious education remains a priority in accordance with the curriculum developed by the boarding school and can continue their education at a higher level and get a job with the provision of religious values. At this stage of the management and implementation of educational programs, Tuan Guru establishes the form of waivers to students who are poor, in terms of the economy to remain education, then freed of all forms of tuition students. For those students who become orphans and poor children in school are given scholarships and school supplies.

\section{Informal of Education}

Informal education development conducted by Tuan Guru appears from some form of educational programs through interpersonal interactions with the study groups in society, as well as guidance developed through extracurricular program students. Form of informal education program developed Tuan Guru namely Diniyah education program students. Diniyah education students was initially a recitation Halaqah without any age restrictions for students to participate in a study program organized by Tuan Guru, as well as study material given is not based on formal education students. That is the fruit of the book that taught by master teacher can be followed by all students of all levels of education together sitting in one Halaqah, in addition there is no book exam or evaluation of the educational program (Akbar, 2012; M. I. Fitriani, 2016; Lubbe, 1986). Diniyah program developed by Tuan Guru is a form of development of the system recitals Halakah previously, the essence of teaching Halaqah like material book which is used as a study, methods used, and the target recitals are still visible and unchanged until today, but the technical and change to the direction of development. In the implementation of the program Diniyah students at the level of junior and senior school done separately, either in writing or hours of implementation, material or books that are used, this is done to make it easier to determine the ability of a student or students toward mastery of the material of the book that has been given by Tuan. Guru or cleric / ustadah has been entrusted to teach at the Diniyah. Moreover, this activity is also equipped with the attendance list prepared in accordance with their class on formal education. This is done because the students 
who follow the formal education required to attend lectures on program activities Diniyah students, while the students who did not attend the activities Diniyah given sanction in the form of environmental hygiene to show discipline students.

Some technical implementation Diniyah education of these students, there is an evaluation program that is held in the form of book examination, carried out on each complete one book. If there were students who could not take the test, then held a supplementary exam with oral exam techniques which directly held by a caregiver. The exam technique used to measure the mastery of students by sitting cross-legged in space Mushalla or mosques, but this technique is less effective and efficient because it provides a great opportunity for students to work together in answering, because the seat between the students one by other students who are very close together.

\section{CONCLUSIONS}

Development of education in rural areas cannot be separated from the role of Tuan Guru as a religious figure who occupied a strategic role in society, that is to say; besides being a figure, educator and mentor community, Tuan Guru is also a solidarity center. Tuan Guru was instrumental in the development of education in rural areas, especially in developing education through Elementary School, Junior School and High School, the establishment of several private schools is the desire of the community itself on community initiatives and master teacher in the village the. Tuan Guru relationships with the community goes well, giving rise to the trust of the community, and the community feel responsible for the progress and development of the madrasah, so it would be a good educational development in line with expectations together. A harmonious relationship between Tuan Guru as community leaders and religious leaders foster a sense of shared responsibility so that they will work together to develop education through community participation. Educational development activities in rural communities cannot take the initiative itself in participating, it takes motivation or support of various parties to the ability of people to participate in the development of more advanced education. Required public figures and prominent role in improving the mindset of people to participate in the development of education. The existence of Master Teachers in a village very influential in the development of management education. Tuan Guru is expected to be more active and continues to provide motivation to the community for the community to understanding the benefits of education for the life of the nation. Because it is the spirit of community participation for the development of education, so it is expected Tuan Guru active role in providing guidance and encouragement to the rural community, because the community is the most important element for the development of education in the era of regional autonomy. Then the community is the result of education. That is why the role of Tuan Guru in the development of education should optimal.

\section{REFERENCES}

Abdullah, L. H. (2011). Latest Development of Traditional Islamic Education in Kelantan. INTED 2011 Proceedings. Kuala Lumpur: INTED, 2193-2198.

Ajam, M. (1989). Islamic schools of Cape Town as agencies of socialization. Journal for Islamic Studies, 9, 70.

Akbar, S. (2012). Kajian Sosiologi Sastra dan Nilai Pendidikan dalam Novel Tuan Guru Karya Salman Faris. UNS (Sebelas Maret University).

Aswasulasikin, Septu Marsa Ibrahim, D. (2016). The Development of Elementary School Education Based on the Rural Community. In Proceding.

Aswasulasikin, A., Dwiningrum, S. I. A., \& Sumarno, S. (2015). Tuan Guru Sebagai Tokoh Pembangunan Pendidikan Di Pedesaan. Jurnal Pembangunan Pendidikan: Fondasi Dan Aplikasi, 3(1), 1-10.

Aswasulsikin, A. (2015). Pembangunan Pendidikan (UNY 2015). Jurnal Pembangunan Pendidikan: Fondasi Dan Aplikasi.

Cypress, B. (2018). Qualitative Research Methods: A Phenomenological Focus. Dimensions of Critical Care Nursing, 37(6), 302-309.

Donalek, J. G. (2004). Phenomenology as a qualitative research method. Urologic Nursing, 24(6), 516517.

Dwiningrum, S. I. A. (2011). Desentralisasi dan Partisipasi. Yogyakarta: Pustaka Pelajar.

Fadli, A. (2016). Intelektualisme Pesantren; Studi Geneologi dan Jaringan Keilmuan Tuan Guru di Lombok. El-Hikam, 9(2), 287-310.

Fahrurrozi. (2018). Tuan guru and social change in Lombok, Indonesia. Indonesia and the Malay World, 46(135), 117-134.

Fitriani, F., \& Suasti, Y. (2018). Participation of Educational Institutions in Supporting Halal Tourism Destination Program through Development of Local Culture in East Lombok Regency. Sumatra Journal of Disaster, Geography and Geography Education, 2(1), 156-161.

Fitriani, M. I. (2016). Kepemimpinan Kharismatistransformatif Tuan Guru dalam Perubahan Sosial Masyarakat Sasak-Lombok Melalui Pendidikan. Al-Tahrir: Jurnal Pemikiran Islam, 16(1), 175195.

Franquesa-Soler, M., Barraza, L., \& Serio-Silva, J. C. (2019). Children's learning preferences for the development of conservation education 
programs in Mexican communities. The Journal of Educational Research, 112(1), 28-37.

Geertz, C. (1971). Islam observed: Religious development in Morocco and Indonesia (Vol. 37). Chicago: University of Chicago Press.

Giorgi, A. (1994). A phenomenological perspective on certain qualitative research methods. Journal of Phenomenological Psychology, 25(2), 190-220.

Giorgi, A. (2009). The descriptive phenomenological method in psychology: A modified Husserlian approach. Duquesne University Press.

Hara, A. E., \& Trihartono, A. (2019). The Failure of Islamic Populism: The Case of Indonesia's 2019 Election. 1st Annual Internatioal Conference on Social Sciences and Humanities (AICOSH 2019). Atlantis Press.

Hardianto, H. (2019). Reposition of Historical Pesantren, Madrasah and Integrated Islamic School. Edumaspul: Jurnal Pendidikan, 3(2), 75-86.

Horikoshi, H. (1987). Kiyai dan perubahan sosial. University of California. Di terjemahkan oleh Abdurrahman Wahid. Diterbitakn oleh Perhimpunan Pengembangan Pesantren dan Masyarakat.

Ismah, N. (2016). Destabilising male domination: Building community-based authority among Indonesian female ulama. Asian Studies Review, 40(4), 491-509.

Kruth, J. G. (2015). Five qualitative research approaches and their applications in parapsychology 1. The Journal of Parapsychology, 79(2), 219.

Law, M., Stewart, D., Letts, L., Pollock, N., Bosch, J., \& Westmorland, M. (1998). Guidelines for critical review of qualitative studies. McMaster University Occupational Therapy EvidenceBased Practice Research Group.

Legiarto, A., Legono, D., \& Haryono, H. (2008). Mitigasi Bencana Aliran Debris Sungai Belanting secara Non Struktural Desa Belanting Kecamatan Sambelia Kabupaten Lombok Timur-Nusa Tenggara Barat. Civil Engineering Forum Teknik Sipil, 18(3), 972-978.

Liow, J. C. (2009). Religious education and reformist Islam in Thailand's southern border provinces: The roles of haji Sulong Abdul Kadir and Ismail Lutfi Japakiya. Journal of Islamic Studies, 21(1), 29-58.

Lubbe, G. (1986). Tuan Guru: Prince, Prisoner, Pioneer. Religion in Southern Africa, 7(1), 25-35.

Maggs-Rapport, F. (2000). Combining methodological approaches in research: ethnography and interpretive phenomenology. Journal of Advanced Nursing, 31(1), 219-225.

Marasabessy, B. (2010). Tuan Guru: The Cape Muslim
Philosophy Education System. Hubs-Asia, 10(1). Morhardt, D. J., O'Hara, M. C., Zachrich, K., Wieneke, C., \& Rogalski, E. J. (2019). Development of a psycho-educational support program for individuals with primary progressive aphasia and their care-partners. Dementia, 18(4), 1310-1327.

Paley, J. (2018). Phenomenology and qualitative research: Amedeo Giorgi's hermetic epistemology. Nursing Philosophy, 19(3), e12212.

Tahir, M. (2008). Tuan Guru dan Dinamika Hukum Islam di Pulau Lombok. ., 42(1), 85-115.

Ticusan, M. (2012). Training for Being a Parent. Procedia - Social and Behavioral Sciences, 69. 1585-1589. https://doi.org/10.1016/j.sbspro.2012.12.102

Ward, J. K., Comer, U., \& Stone, S. (2018). On qualifying qualitative research: emerging perspectives and the "deer"(descriptive, exploratory, evolutionary, repeat) paradigm. Interchange, 49(1), 133-146.

Wardatun, A., Amrullah, A., \& Musta'in, M. (2015). Confirming Domestic Identity, Supporting Public Commitment (The Case of Tuan Guru's Wife in Lombok West Nusa Tenggara Eastern Indonesia). Musãwa Jurnal Studi Gender Dan Islam, 14(2), 171-184.

Yafie, A. (1997). Teologi Sosial, Telaah Kritis Persoalan Agama dan Kemanusiaan. Yogyakarta: LKPSM.

Yani, A. (2017). Pemikiran Tuan Guru Subki Sasaki Tentang Pendidikan Liberal (Studi Tokoh Subki Sasaki Tentang Pendidikan Kebangsaan, Keagamaan, dan Kebudayaan). DISERTASI Dan TESIS Program Pascasarjana UM. 